NBER WORKING PAPER SERIES

\title{
MULTINATIONAL ENTERPRISES, INTERNATIONAL TRADE, AND PRODUCTIVITY GROWTH: FIRM LEVEL EVIDENCE FROM THE UNITED STATES
}

\author{
Wolfgang Keller \\ Stephen R. Yeaple \\ Working Paper 9504 \\ http://www.nber.org/papers/w9504
NATIONAL BUREAU OF ECONOMIC RESEARCH
1050 Massachusetts Avenue
Cambridge, MA 02138
February 2003

We thank Andy Bernard, Jacques Mairesse, Marc Rysman, Carol Shiue, and seminar audiences at Boston College, Boston University, Brown University, Columbia University, Stanford University, the University of Texas, and Yale University, as well as at CEPR's ERWIT 2002 and the NBER Summer Institute 2002 conference for comments. We are also grateful to Wayne Gray and Bill Zeile for help with the data and useful conversations. The statistical analysis of firm-level data on U.S. multinational corporations reported in this study was conducted at the International Investment Division, U.S. Bureau of Economic Analysis, under arrangements that maintained legal confidentiality requirements. Views expressed are those of the authors and do not necessarily reflect those of the Bureau of Economic Analysis. The views expressed herein are those of the authors and not necessarily those of the National Bureau of Economic Research.

C2003 by Wolfgang Keller and Stephen R. Yeaple. All rights reserved. Short sections of text not to exceed two paragraphs, may be quoted without explicit permission provided that full credit including notice, is given to the source. 
Multinational Enterprises, International Trade, and Productivity Growth:

Firm-Level Evidence from the United States

Wolfgang Keller and Stephen R. Yeaple

NBER Working Paper No. 9504

February 2003

JEL No. F1, F2, O3

\begin{abstract}
We estimate international technology spillovers to U.S. manufacturing firms via imports and foreign direct investment (FDI) between the years of 1987 and 1996. In contrast to earlier work, our results suggest that FDI leads to significant productivity gains for domestic firms. The size of FDI spillovers is economically important, accounting for about $14 \%$ of productivity growth in U.S. firms between 1987 and 1996. In addition, there is some evidence for imports-related spillovers, but it is weaker than for FDI. The paper also gives a detailed account of why our study leads to results different from those found in previous work. This analysis indicates that our results are likely to generalize to other countries and periods.
\end{abstract}

\author{
Wolfgang Keller \\ Economics Department, Box B \\ Brown University \\ 64 Waterman Street \\ Providence, RI 02906 \\ and NBER \\ Wolfgang_Keller@brown.edu \\ Stephen R. Yeaple \\ Department of Economics \\ University of Pennsylvania \\ 3718 Locust Walk \\ Philadelphia, PA 19104 \\ snyeap12@ssc.upenn.edu
}




\section{Introduction}

Much of the variation in living standards across countries can ultimately be traced back to differences in productivity (Hall and Jones 1999, Trefler 1995). What explains these differences in productivity? Recent work shows that variation in cross-country productivity is at least as much due to foreign as due to domestic innovation (Eaton and Kortum 1999, Keller 2002a). It suggests that to better understand cross-country variation in productivity, we may need to learn more about the international transfer of technology.

Foreign direct investment (FDI) and trade have long been suspected to be major conduits of international technology transfer. Both have grown faster than GDP recently, and foreign-owned companies account now for almost one-sixth of U.S. manufacturing GDP, for example. ${ }^{1}$ It is thus now more important than ever to ascertain whether in fact FDI and trade do lead to international technology transfer. Policy prescriptions of international organizations such as the World Bank and the World Trade Organization are critical of discriminatory policies towards foreign investors and exporters. And far from discriminating against foreigners, countries all over the world spend large amounts of resources to attract foreign multinationals, on the assumption that FDI leads to technology transfer and subsequent productivity gains for domestic firms. To give but one recent example: the U.S. state of Alabama has spent $\$ 230$ million $(\$ 150,000$ per newly created job) to attract a new plant of Mercedes in 1994 (Head 1998). ${ }^{2}$ Such large subsidies can only be justified if FDI, or imports for that matter, generate substantial

\footnotetext{
${ }^{1}$ See Zeile (2002) and U.S. national accounts data at www.bea.gov.

${ }^{2}$ Hanson (2001) and Görg and Greenaway (2002) discuss other major cases, as well as the broader evidence indicating that in contrast to the 1960s and 1970s, recently foreign investment has been favored relative to domestic investment. The value of the FDI incentives is typically the present discounted value of the sum of direct subsidies, e.g. in form of the publicly provided infrastructure, and tax reductions.
} 
positive externalities, or technology spillovers for domestic firms. In this paper, we will estimate the size of spillovers associated with imports and the activities of multinational enterprise (MNE) affiliates that constitute FDI.

Notwithstanding large subsidies given to multinationals, the conventional wisdom on FDI spillovers today is that they do not exist or are at best of minor economic importance (see section 2). Our analysis revisits this view. With a sample of about 1,100 U.S. firms for the years 1987 to 1996, we find evidence for substantial FDI spillovers: according to our preferred estimates, FDI spillovers accounted for about $14 \%$ of U.S. productivity growth over this period. There is also some support for imports-related technology spillovers, but overall our evidence on imports is less conclusive.

A second contribution of this paper is that we give an account of possible reasons for our high spillover estimates relative to the large literature that found only minor effects. For instance, if our different finding were due to an improved estimation, it would be more likely to be a general result than if it were due to a particular sample. It appears that our results are primarily due to improved measurement of foreign multinational activity. On this basis, we argue that our results are likely to generalize once such data is available in other circumstances as well.

The following section briefly reviews the evidence on technology spillovers associated with imports and FDI, before we present our model and the estimation framework in section 3. Section 4 gives an overview of the data, with more detail provided in the appendix. All estimation results can be found in section 5, while section 6 contains some concluding summary and discussion. 


\section{Technology spillovers through trade and FDI}

Imports and inward FDI have often been emphasized as being spillover channels. Importing a technologically advanced commodity might trigger learning that enables domestic producers to manufacture a similar good at lower costs at home. Another possibility is that the price does not fully reflect the quality of the imported good, which might be due to market power on the part of the buyer or problems of appropriability for the seller.

FDI might also be associated with spillovers for domestic firms because workers that embody the firm-specific knowledge asset of the MNE affiliate can be attracted to domestic firms (Fosfuri, Motta, and Rønde 2001), because multinationals give access to new specialized intermediate inputs (Rodriguez-Clare' 1996), or because domestic firms use local intermediate goods suppliers whose productivity has been raised through the know-how of the MNE. In these and other instances, it is a priori plausible that market prices do not necessarily reflect the full benefits and costs.

Several authors have recently examined the question of whether there are technological externalities associated with trade. A first set of papers has looked for international R\&D spillovers driven by imports. In an influential paper, Coe and Helpman (1995) have related productivity to the import-share weighted R\&D of the countries' trade partners, estimating a positive regression coefficient. Xu and Wang (1999) have strengthened these results by focusing on machinery instead of all imports.

At the same time, Keller (1998) generates almost as strong results with counterfactual instead of observed import data. This underlines that the evidence for imports-related technology spillovers on the basis of these regressions is not very strong. More recent 
research has sought to provide a more powerful empirical framework by employing more disaggregated data and allowing for alternative spillover channels in addition to imports. This has produced mixed results so far: for instance, Keller's (2002b) industry-level analysis of technology spillovers among the G-7 countries finds evidence in support of imports-related effects, while Kraay, Isoalaga, and Tybout (2001) in their study of firm productivity dynamics in three less developed countries do not. ${ }^{3}$

A number of different methods have been employed to study FDI spillovers. There are, first of all, a number of case studies of recent large-scale FDI, and these studies have produced somewhat mixed results. ${ }^{4}$ Outside the event-study literature, an increasing number of authors have estimated FDI spillovers using data on repeated crosssections of firms or plants. This has a number of advantages relative to cross-sectional estimation at the industry or aggregate level; for instance, it is less likely to lead to spurious results due to unobserved heterogeneity.

Among these studies, Aitken and Harrison (1999) find that an increase in the presence of foreign-owned affiliates is associated with lower productivity in a sample of Venezuelan plants in the late 1970s and 1980s. The authors attribute this result to strong competition and average cost effects - e.g., incoming foreign-owned affiliates hire the most highly skilled workers away from domestic plants - that outweigh any positive FDI spillovers that might exist. Girma and Wakelin (2001) as well as Haskel, Pereira, and Slaughter (2001) have studied inward FDI for the United Kingdom while trying to

\footnotetext{
${ }^{3}$ Analogous to imports, other work has provided evidence on learning externalities associated with exports; it is relatively weak so far as well (e.g., Clerides, Lach, and Tybout 1998). See Keller (2001) for further results and discussion.

${ }^{4}$ Larrain, Lopez-Calva, and Rodriguez-Claré (2000) argue that Intel's investment in Costa Rica in 1997 generated substantial benefits for the local economy, whereas Hanson's (2001) discussion of three other recent cases suggests spillovers are non-existent or small.
} 
control for changes in the degree of competition to isolate FDI spillover effects. Both studies find evidence for positive FDI spillovers, although the estimated productivity effects for U.K. plants are small: according to Haskel, Pereira, and Slaughter (2001), e.g., FDI spillovers account for only about $5 \%$ of the TFP growth in British manufacturing in the two decades from 1973 to $1992 .^{5}$

Summarizing, there is some evidence for imports-related technology spillovers, but it is far from ubiquitous, and in particular, the evidence becomes weaker when micro data and econometrics based on an explicit behavioral model is used. With respect to FDI, there too is stronger evidence for spillovers when more aggregated data is employed. Among the panel studies based on micro data (to which this literature has gravitated), only two find statistically significant positive effects of FDI on domestic firm productivity, and these effects are small in an economic sense. In conclusion, there is no evidence for strong positive technology spillovers associated with FDI. ${ }^{6}$ Naturally, this would imply that providing substantial subsidies to multinationals to facilitate technology transfer to domestic firms is a misguided policy.

We now turn to our analysis that revisits these issues.

\section{Model and estimation framework}

Since there is no consensus on the existence of strong spillovers, we take a broad view on how FDI and imports might affect the productivity of domestic firms. Instead of

\footnotetext{
${ }^{5}$ This discussion has focused on estimates of the magnitude of intra-industry FDI spillovers in terms of domestic productivity, which constitutes the largest and most influential literature. Another approach is to identify technology transfer by patent citations; Branstetter (2000), e.g., shows that FDI between the U.S. and Japan is associated with higher knowledge flows in terms of patent citations of U.S. and Japanese firms. Two studies emphasizing the importance of inter-industry spillovers are Blalock and Gertler (2002) as well as Kugler (2002). We will return to the question of inter-industry FDI spillovers in section 6. ${ }^{6}$ Two recent surveys come to the same conclusion, see Hanson (2001), Görg and Greenaway (2002).
} 
modeling a particular mechanism, our approach is to ask whether there is evidence for higher productivity of domestic firms in industries when there is more foreign activity in terms of FDI and imports. By and large, this is the question that has been asked so far, with the answer being non-affirmative (see section 2 above).

Our analysis relies on correctly measuring firm productivity. To this end we employ the methodology developed by Ericson and Pakes (1995) and Olley and Pakes (1996). ${ }^{7}$ These authors develop a framework for dynamic industry equilibrium analysis where firms optimally choose sales and investment, as well as entry and exit. For our purposes, two aspects of the Olley and Pakes approach are most important: first, it allows for firm-specific productivity differences that exhibit idiosyncratic changes over time, and second, the model endogenizes the firm's liquidation decision by generating an exit rule. These features address two major concerns that have afflicted productivity calculations for a long time: simultaneity and selection biases. To see this, consider the following equation:

$$
y_{i t}=\beta_{0}+\beta_{l} l_{i t}+\beta_{m} m_{i t}+\beta_{k} k_{i t}+u_{i t}
$$

where $y_{i t}$ is the logarithm of output of firm $i$ at time $t$, and correspondingly, $1_{i t}, m_{i t}$, and $k_{i t}$ are the firm's (log of) labor, materials, and capital inputs. The last term, $\mathrm{u}_{\mathrm{it}}$, is an error representing all disturbances that prevent (1) from holding exactly. Let this term be composed of two parts,

$$
u_{i t}=\omega_{i t}+\eta_{i t}
$$

Consider the case when neither $\omega_{i t}$ and $\eta_{i t}$ are observed by the econometrician, whereas the firm cannot observe $\eta_{i t}$, but it does know $\omega_{\text {it. }}$ The term $\eta_{\text {it }}$ could be capturing

\footnotetext{
${ }^{7}$ The following introduces only the most salient features of their approach. See also Griliches and Mairesse (1995) for more discussion of the relative strengths and weaknesses of the Olley-Pakes approach.
} 
unpredictable demand shocks while $\omega_{\text {it }}$ could be firm productivity, for instance. If $\omega_{\text {it }}$ is known to the firm, the optimal labor input choice will be a function of $\omega_{\mathrm{it}}$, and simple OLS estimation will suffer from a simultaneity bias because $E\left[u_{i t} \mid l_{i t}\right] \neq 0 .{ }^{8}$ If the term $\omega_{\text {it }}$ is constant over time, $\omega_{\mathrm{it}}=\omega_{\mathrm{i}}$, all $\mathrm{t}$, taking time- or within-firm differences of (1) and proceeding with OLS on the transformed data can lead to consistent parameter estimates. But in our framework, $\omega_{\text {it }}$ is firm productivity, and how this changes in relation to imports and FDI is exactly the question we are asking. This strategy is therefore ruled out. As shown below, we will identify $\omega_{\text {it }}$ from the firms' investment choices. Knowing $\omega_{\text {it }}$ allow us to control for the simultaneity of input choices, and thus to avoid this bias.

We now turn to the selection problem. The firm maximizes the expected discounted value of its future net cash flows. At the beginning of the period, the firm learns its productivity $\omega_{\mathrm{it}}$, which is assumed to evolve according to an exogenous Markov process. Then, the firm makes three choices. It decides whether to exit or not, it chooses variable factors (labor and materials), and how much to invest in capital. For a sufficiently low value of $\omega_{\mathrm{it}}$, a firm's value of continuing in operation will be less than some (exogenous) liquidation value, and it will exit; call the threshold level at which a firm is indifferent between exiting and staying $\underline{\omega}_{t}$.

One can show that if the firm's per-period profit function is increasing in $\mathrm{k}$, the value function must be increasing in $\mathrm{k}$ as well, while $\underline{\omega}_{t}$ is decreasing in $\mathrm{k}$. The reason is that a firm with a larger capital stock can expect larger future returns for any given level of current productivity, so that it will remain in operation at lower realizations of $\omega_{\text {itt }}$.

\footnotetext{
${ }^{8}$ The existence of this bias depends on the possibility that input choice can be varied; this explains why we use the example of labor as an input, which is generally considered to be not subject to large adjustment costs. In the multivariate case, the OLS bias can usually not be unambiguously signed. However, if labor and capital are positively correlated, and labor is more strongly correlated with $\omega_{\text {it }}$ than capital, then OLS will tend to overestimate $\beta_{1}$ and underestimate $\beta_{\mathrm{k}}$.
} 
Relatively small firms exit at productivity draws for which relatively large firms would have continued to operate, so that the relatively small firms that stay in the market tend to be those that received unusually favorable productivity draws. The correlation between $\omega_{\mathrm{it}}$ and $\mathrm{k}_{\mathrm{it}}$ is negative, and failing to account for the self-selection induced by exit behavior will lead to a negative bias in the capital coefficient. The Olley and Pakes approach generates an exit rule, so that we can account for this self-selection and avoid the associated bias.

In terms of estimation, we take the following steps. In equations (1), (2), we assume that labor and materials are variable inputs so that their choice is affected by $\omega_{\mathrm{it}}$, whereas capital $\mathrm{k}_{\mathrm{it}}$ is only determined by past values of $\omega$, not the current one. Dropping the firm subscript for ease of notation, let $i_{t}$ be the firm's optimal investment choice at time t. Provided that $i_{t}>0$, it is possible to show that investment is strictly increasing in $\omega_{\mathrm{t}}$ for any $\mathrm{k}_{\mathrm{t}}{ }^{9}{ }^{9}$ This means that the investment function can be inverted to yield

$$
\omega_{t}=h_{t}\left(i_{t}, k_{t}\right)
$$

Substituting (3) and (2) into (1) gives

$$
y_{t}=\beta_{l} l_{t}+\beta_{m} m_{t}+\phi_{t}\left(i_{t}, k_{t}\right)+\eta_{t},
$$

with $\phi_{t}\left(i_{t}, k_{t}\right)=\beta_{0}+\beta_{k} k_{t}+h_{t}\left(i_{t}, k_{t}\right)$. Because $\phi_{t}($.$) contains the productivity term$ $\omega_{t}=h_{t}($.$) that is the source of the simultaneity bias, equation (4) can be estimated to$ obtain consistent estimates $\beta_{1}$ and $\beta_{\mathrm{m}}$ on the variable inputs, labor and materials. Equation (4) is a partially linear regression model of the type analyzed by Robinson (1988), and we

\footnotetext{
${ }^{9}$ The requirement that investment must be positive may be limiting for some applications. Levinsohn and Petrin (2001) propose therefore a variant of Olley and Pakes' approach in which productivity is identified from materials inputs (which is usually greater than zero). In our sample, the zero-investment problem is negligible.
} 
use a fourth-order polynomial in investment and capital to capture the unknown function $\phi_{t}(.) .^{10}$

With consistent estimates of $\beta_{1}$ and $\beta_{\mathrm{m}}$ in hand, we proceed to estimating the effect of capital on output, $\beta_{\mathrm{k}}$, which is not identified in (4) because it is combined with capital's effect on investment. We assume for simplicity that $\mathrm{k}_{\mathrm{t}}$ is uncorrelated with the innovation in $\omega_{\mathrm{t}}, \xi_{t}=\omega_{t}-\omega_{t-1}$, or, $\omega_{\mathrm{t}}$ is a random walk (this can be generalized).

Substituting this into (4) gives

$$
y_{t}-\hat{\beta}_{l} l_{t}-\hat{\beta}_{m} m_{t}=\beta_{k} k_{t}+\hat{\phi}_{t-1}-\beta_{k} k_{t-1}+\xi_{t}+\eta_{t}
$$

where $\hat{\phi}_{t-1}$ comes from estimating (4), and $\hat{\phi}_{t-1}-\beta_{k} k_{t-1}$ is an estimate of $\omega_{t-1}$.

The probability of survival to period $t$ depends on $\omega_{\mathrm{t}-1}$ and $\underline{\omega}_{t-1}$, the unobserved level of productivity that would make a firm shut down its operations, which can be shown to depend only on capital and investment at time t-1. We generate an estimate of the survival probability by running a probit regression on a fourth-order polynomial in capital and investment (lagged by one period); the estimated survival probability is denoted by $\hat{P}_{t}$. The final step is to estimate $\beta_{\mathrm{k}}$ from the resulting equation:

$$
y_{t}-\hat{\beta}_{l} l_{t}-\hat{\beta}_{m} m_{t}=\beta_{k} k_{t}+g\left(\hat{\phi}_{t-1}-\beta_{k} k_{t-1}, \hat{P}_{t}\right)+\xi_{t}+\eta_{t}
$$

Here we approximate the unknown function $\mathrm{g}($.$) by a fourth-order polynomial in$ $\hat{\phi}_{t-1}-\beta_{k} k_{t-1}$ and $\hat{P}_{t} ; \beta_{\mathrm{k}}$ is then estimated non-linearly across all terms that contain it.

\footnotetext{
${ }^{10}$ This includes all cross terms, and we allow this function to vary over time for the subperiods 1987-90, 1991-1993, and 1994-1996.
} 
Using the estimates of coefficients of labor, materials, and capital, we estimate $\log$ total factor productivity as $t f p_{i t}=y_{i t}-\hat{\beta}_{l} l_{i t}-\hat{\beta}_{m} m_{i t}-\hat{\beta}_{k} k_{i t}$. Our empirical analysis relates firms' TFP growth, $\Delta t f p_{i t}$, to changes in the degree of foreign activity through imports $\left(\Delta I M_{i t}\right)$ and FDI $\left(\Delta F I_{i t}\right)$ at the industry level:

$$
\Delta t f p_{i t}=\beta X_{i t}^{\prime}+\gamma_{1} \Delta I M_{i t}+\gamma_{2} \Delta F I_{i t}+e_{i t}
$$

where $\mathrm{X}^{\prime}{ }_{i t}$ is a vector of control variables, and $e_{i t}$ is an error term; the exact definitions of $\Delta I M_{i t}, \Delta F I_{i t}$, and $\mathrm{X}^{\prime}{ }_{\mathrm{it}}$ are discussed in the following data section.

\section{Data}

This study is based on data on an unbalanced sample of manufacturing firms in the United States from Standard and Poor's Compustat database. Compustat includes only publicly traded companies and publishes data from the companies' balance sheets according to legal reporting requirements. Unlike census data, the Compustat database has the advantage of being publicly available. Moreover, it includes most of the larger U.S. firms, which means that- as in Griliches and Mairesse (1984), as well as Jovanovic and Rousseau (2002), e.g.- we cover the major portion of all U.S. economic activity. As we show below (see 5.1), the cross-industry variation in our productivity estimates resembles closely that of U.S. manufacturing as a whole.

Our sample consists of a total of 1,115 U.S.-owned firms that were active between the years 1987 to 1996 , covering about 58\% percent of U.S. manufacturing employment and roughly $70 \%$ of U.S. manufacturing research and development expenditures. From Compustat, we obtain data on the firms' $(\log )$ output y, as well as $(\log )$ labor, materials, 
and capital inputs $(1, \mathrm{~m}$, and $\mathrm{k})$, where our output measure is net sales. ${ }^{11}$ Firm sales are deflated by a common deflator at the three-digit SIC level that we have constructed from the Bartelsman and Gray (2001) NBER Productivity data base, while the deflators for the capital stock come from the Bureau of Labor Statistics. Also from Compustat comes data on the firms' R\&D expenditures, which is a likely determinant of productivity; log R\&D expenditures are denoted by $r_{i t}$. Not all data is available for all firms; for instance, a significant number of firms (about 15\%) do not report material input usage. In some cases we have had to fill in small amounts of missing data, typically for the firms' capital stocks. $^{12}$

Our primary interest is whether productivity is related to the importance of imports and foreign-owned affiliates in the firm's relevant economic environment. We measure the importance of imports for a given firm by the share of U.S. imports in imports plus total shipments of the industry to which the firm belongs; this variable is denoted by $I M_{i t}$. Correspondingly, the importance of FDI is measured by the share of foreign affiliate employment in total employment of the industry to which the firm belongs (denoted by $F I_{i t}$ ). Our analysis is at a relatively detailed, two to three-digit SIC, industry level. This is determined by the roughly 50 industries in which the U.S. Bureau of Economic Analysis (BEA), responsible for reporting U.S. FDI data, is classifying total manufacturing activity; see Table 1 for a list of the industries. For our sample period we

\footnotetext{
${ }^{11}$ Data on the flow of materials usage is estimated from the change in the firm's stock of materials; for this and other details of the variables' definitions and construction, see the appendix.

${ }^{12}$ Because large firms often span several industries, our matching of firms to industries is imperfect and introduces measurement error in our dependent variable. A different part of Compustat contains more detailed (line of business) data for sales, but unfortunately not for all inputs. Analyzing productivity at the plant instead of the firm level might help; not infrequently though, plants are operating in several industries as well. To address measurement error concerns, we conduct a wide-ranging robustness analysis.
} 
choose the years 1987 to 1996 , because before and after this period there have been changes in the BEA's industry classification.

Data on foreign employment comes from confidential affiliate level data collected by the BEA in its annual surveys. This data is aggregated from the affiliate level to the level of the industry classification that we use. The employment figures are based on the industry classification of the activity of individual affiliate employees rather than the industry classification of the affiliate as a whole, by its mainline of business. ${ }^{13}$ The former is preferred, because it avoids the sudden shifts of a large number of employees from one industry to another industry that is associated with data on employment for the entire affiliate if the affiliate's mainline of business changes. The imports data is obtained from Feenstra (2002), and the values for total shipments and employment by industry come from Bartelsman and Gray (2001).

These measures of imports and FDI broadly capture the prevalence of foreign economic activity in a particular U.S. industry. If specialized imports are important in triggering technology spillovers, or if foreign affiliates of MNEs generate positive externalities for U.S. firms by building up more efficient supplier chains or a pool of highly skilled technicians, it is plausible that this is correlated with our measures of foreign presence in that industry. ${ }^{14}$

\footnotetext{
${ }^{13}$ An affiliate's mainline of business is the industry in which the affiliate has the majority of its sales. In BEA's annual surveys of foreign direct investment in the United States for the years covered in this study, large affiliates were required to specify their employment (as well as sales) in the eight industries in which their sales were largest; other affiliates had to specify their employment (and sales) in the three industries in which their sales were largest.

${ }^{14}$ These measures will not be able to pick up externalities that are generated between major industries (vertical production specialization); however, many important buyer-supplier relationships will be within our still relatively broadly defined industry classification. Another interesting aspect that we do not cover is the spatial dimension of technology spillovers, in particular, whether they are geographically localized. Keller (2001) reviews some of the evidence.
} 
The Olley and Pakes method of computing firm productivity addresses the problem of simultaneity in input choices, but the endogeneity of imports or FDI could be an issue as well. For instance, FDI could be attracted to industries in which productivity is growing relatively fast on average. This would lead to a positive correlation of FDI and productivity which does not provide evidence for FDI spillovers. ${ }^{15}$ Instrumental variable estimation is a way to address this issue; however, here we do not have good instruments, because the variables that are highly correlated with FDI and imports are also likely to be correlated with productivity. Instead, endogeneity issues of this kind are addressed by considering the effect of both contemporaneous and lagged foreign activity on productivity, as well as other robustness analysis.

A number of other variables will be employed to better isolate spillover effects (see the appendix for variable construction). First, we include a variable that picks up the degree of capacity utilization (denoted as CU). For instance, the number of workers a firm hires is likely to be positively related to both hours worked as well as sales, which means that we might be overestimating the coefficient on labor if capacity utilization is not controlled for. Second, we have noted above that it is important to control for changes in the degree of market competition that might be associated with changes in foreign activity. We follow Nickell (1996) and others and use the firm's market share in the industry as well as the firm's mark-up and the industry mark-up to capture these effects (denoted by MS, FM, and SM, respectively). To the extent that a higher market share or a higher firm mark-up, conditional on the industry's overall mark-up indicate less

\footnotetext{
${ }^{15}$ Alternatively, it could be that FDI is attracted to weak domestic industries to capture these markets. In that case, the correlation of cross-industry productivity growth and inward FDI might well be negative.
} 
competitive pressures, we expect that a firm's productivity growth slows down, all else equal.

There is a substantial degree of unobserved heterogeneity across firms in different industries in our sample. Productivity growth in some industries is higher than in others due to factors unrelated to imports and FDI, an example being the advances in the information technology and communications industry during our sample period. We therefore allow for exogenous differences in productivity growth across industries by including industry fixed effects, $\alpha_{\mathrm{j}}$, in the specifications below. We also include time fixed effects, $\alpha_{t}$, in all regressions, because our sample period covers the 1990/91 U.S. recession. The baseline estimation equation is given by

$$
\begin{aligned}
\Delta t f p_{i t}= & \alpha_{j}+\alpha_{t}+\beta_{1} r_{i t}+\beta_{2} \Delta C U_{i t}+\beta_{3} \Delta M S_{i t-2}+\beta_{4} F M_{i t-2}+\beta_{5} S M_{i t-2} \\
& +\gamma_{1} \Delta I M_{i t}+\gamma_{2} \Delta F I_{i t}+\varepsilon_{i t} .
\end{aligned}
$$

Here, $\varepsilon_{i t}$ is a mean-zero error term, and $\Delta$ indicates a one-year difference, so that $\Delta F I_{i t}$, for example, is the change in the share of foreign-affiliate employment in total employment in consecutive years.

We now turn to the empirical results.

\section{Empirical Analysis}

It is useful to analyze the main trends over the sample period by industry before discussing the regression results. There are large differences across industries. For instance, there are three industries for which the firms' labor input is declining on average by more than 5\% annually (Grain mill products [SIC 204], Beverages [SIC 208], and Apparel [SIC 230]), while at the same time there are four industries for which 
employment is growing annually by more than $5 \%$ per year on average (these are Drugs [SIC 283], Metal cans [SIC 341], Farm and garden machinery [SIC 352] and Specialized industry machinery [SIC 355]).

The U.S. firms in our sample have increasingly been exposed to import competition. In 1987, the average ratio of imports to imports plus shipments was $12.9 \%$, while by 1996 , this import share had risen to $16.5 \%$. The annual growth of imports these firms were facing was almost twice as high as the growth in industry shipments. In addition, the increase in the import share has been more or less monotonic. There has been a substantial amount of variation across industries, however. Between 1987 and 1996 the import share in apparel grew by 8.7 percentage points, whereas it fell for motor vehicles by about 2.6 percentage point, as Table 2 indicates.

The share of U.S. manufacturing employment accounted for by foreign-owned affiliates has been growing over time as well, from $7.7 \%$ in 1987 to $11.7 \%$ in 1996 . However, in this case, we can distinguish two separate phases of FDI dynamics. Between 1987 and 1993, FDI grew particularly strongly, from $7.7 \%$ to $11.6 \%$. In the aftermath of the 1991 recession, however, the pace of FDI into the U.S. slowed down, and in 1996 the share is $11.7 \%{ }^{16}$ There were differences across industries, with FDI growing in food manufacturing by 1.5 while growing in motor vehicles by 8.0 percentage points. It is no accident that the industry that experienced the second-largest FDI increase-motor vehicles — is also the industry where the import share has least increased: overall, the correlation in Table 2 between changes in import and FDI tends to be negative, although not significantly so.

\footnotetext{
${ }^{16}$ The general trend towards greater internationalization has continued, however. According to the latest available figures from the BEA and the Bureau of Labor Statistics (BLS), in the year 2000, the share of foreign employment in U.S. manufacturing was 14.4\%; see Zeile (2002) and www.bls.gov.
} 
Figure 1 compares the sales shares in our sample with the sales shares in the NBER Productivity Data Base, Bartelsman and Gray (2001), each by BEA industry average over the sample period. Clearly, our sample does not exactly reflect the relative industry sizes in U.S. manufacturing as a whole. For instance, the figure shows that we have a substantially larger share of computer industry firms (SIC 357) in our sample than exists in the U.S. economy as a whole, while other industries such as motor vehicles (SIC 371), appear to be somewhat underrepresented in our sample. While we note that the rank correlation of BEA industry sales shares in the two samples is positive (and significant), the composition of our sample will have to be taken into account when we interpret the results.

\subsection{Olley-Pakes Production Function Elasticities}

Table 3 reports the production elasticities for capital, labor, and materials that we estimate using the Olley-Pakes (O-P) method described above. We have tried several specifications that differ in the set of variables that is included as right-hand side variables in stage one, equation (4) from above, and columns 1 and 2 in Table 3 give some indication of the range of estimates that is obtained. ${ }^{17}$ In specification O-P (1), we follow Griliches and Mairesse (1995) by including a general trend and a differential trend for computers as regressors in the first stage, because the computer industry has experienced exceptionally high productivity growth over this period. The elasticities are estimated to be $0.300,0.466$, and 0.256 for capital, labor, and materials, respectively. Without the trends, the capital elasticity falls to 0.251 (see O-P (2)).

\footnotetext{
${ }^{17}$ These specifications differ in (1) whether we allow the investment function to vary over time or not; (2) whether we use capital investment, or capital investment plus acquisitions minus divestitures; and (3) whether we include R\&D expenditures as a regressor or not.
} 
For comparison purposes, we also show the OLS estimates of the elasticities.

These lead to significantly lower capital and materials estimates, with 0.200 and 0.164 , respectively; these results are consistent with simultaneity and exit leading to an important downward bias on the capital coefficient. Also on the basis of the estimated scale elasticities (between 0.98 and 1.02 for Olley-Pakes, and 0.83 for OLS), the OlleyPakes estimates seem to be preferred. Firm TFP is therefore computed using the elasticity estimates of the preferred specification O-P (1). Further, we have examined how our TFP growth figures compare to those of the NBER Productivity Database, and found the correlation of the two series to be high. ${ }^{18}$ Our sample reflects the cross-industry variation in productivity growth for U.S. manufacturing as a whole well in this sense. ${ }^{19}$

\subsection{Baseline Results}

Turning to the regression results, we begin by estimating equation (8) using oneyear differences. The benefit of using one-year differences is that we can make maximum use of the time variation in our data. One aspect of this variation that is of critical interest in our analysis is the time span over which spillovers might occur. To this end, we use measures of the change in import and multinational activity that are contemporaneous and lagged one and two years. Because we may exacerbate problems

\footnotetext{
${ }^{18}$ The correlation of average TFP growth in the sample with TFP growth in the NBER database is 0.89 (at the level of the 48 BEA industries of Table 1 , weighted by sales).

${ }^{19} \mathrm{We}$ use the same production function elasticities for computing firm TFP in all industries. This is primarily because we have on average only about 20 firms per BEA industry (and often less), which would make BEA industry-specific elasticity estimates very imprecise. In order to relax the common-elasticity assumption, though, we have estimated separate Olley-Pakes elasticities for broad industry groups. Splitting manufacturing into two groups, the ten low labor- and ten high labor share two-digit industries-based on Bartelsman and Gray (2001)--, for instance, we estimate an O-P labor coefficient of 0.434 for firms in the former, and 0.494 for firms in the latter group. This is in line with expectations. At the same time, these two estimates are not different at standard levels of statistical significance. Moreover, we have confirmed that the restriction of common elasticities does not affect the main imports and FDI spillover results.
} 
of error-in-variables by relying on short-run movements, we experiment with longer time differences below.

The results are shown in Table 4 . The columns correspond to different specifications that vary in the timing of import and MNE activity relative to subsequent TFP growth and to different industry controls. The first four columns correspond to specifications in which we include a full set of industry indicators variables (coefficients suppressed). Allowing for industry controls is crucial if there are unobserved industry characteristics not captured by our controls that might affect both TFP growth rates and the extent of foreign activity as measured by both imports and FDI. In the fifth column we report estimates obtained by estimating equation (8) without industry dummies. In the final column, we report estimates obtained by estimating equation (8) allowing for both industry specific intercepts and time trends. In all cases, the standard errors reported in parentheses are both heteroskedasticity consistent and adjusted for clustering at the level of the firm.

There is data on 839 firms for the specification with a full set of contemporaneous and lagged foreign activity variables and industry fixed effects shown in column one. We first consider the controls. In the first row is the coefficient corresponding to contemporaneous levels of $\mathrm{R} \& \mathrm{D}$ expenditure. The coefficient is positive and statistically significant, indicating that firms that conduct greater research and development efforts do experience faster TFP growth. This result is consistent with the literature as reported by Griliches (1995). In the second row is the coefficient for our capacity utilization variable. The negative coefficient is consistent with the hypothesis that measured TFP rises during periods of intense capital usage. In the third and fourth row are the two-year lagged 
change in firms' market share and the firm's mark-up, included as controls for changing product market competition. Both are negative, the latter marginally significant. This suggests that firms enjoying a strong position in the product market show less TFP growth as would be consistent with non-pecuniary slack enjoyed by monopolists. Our final control is industry average markups, again lagged two years, as shown in the fifth row. Interestingly, the coefficient on industry mark ups is positive and statistically significant, which may reflect cyclical industry effects that are not captured by our measure of capacity utilization.

Turning to the foreign activity variables, rows six through eight show the coefficients for FDI activity; this is defined as the change in the share of MNE affiliate employment in total industry employment, both contemporaneous as well as lagged. The results reveal that current and one-year lagged FDI growth are associated with faster TFP growth while two-year lagged FDI growth is associated with slower TFP growth. Of these three coefficients only the current and one-year lagged variables are statistically significant. The F-test reported at the bottom of the table reveals that as a whole the three coefficients are statistically significant at a high level of confidence. These estimates also suggest that to the extent that there are spillovers from FDI, they have been fully reflected in domestic TFP within two years. ${ }^{20}$

Now consider the coefficients on imports shown in rows nine through eleven. A similar pattern emerges in these coefficients: the current and one-year lagged measures are positive while the two-year lagged measure is negative. Another similarity is that the

\footnotetext{
${ }^{20}$ That the relationship of productivity with FDI lagged twice is estimated to be so different from productivity's relationship with FDI lagged once is consistent with our estimation capturing FDI spillovers; if instead our estimates would pick up primarily common trends or endogeneity, it is not clear why timing would matter that much.
} 
three coefficients are jointly significant at high levels of confidence as indicated by the Ftest at the bottom of the table. Like the two-year lagged FDI measure, the coefficient on two-year lagged imports is not statistically significant on its own. Again, the results are consistent with technology spillovers through imports that occur fairly rapidly.

To confirm our hypothesis on the timing on potential spillovers in the data, we show the results in columns two through four of estimating a single measure of foreign penetration at different lags. In each of these specifications, the time span of the sample varies so that the number of firms in the sample varies across columns as well. The results reported in columns two through four are highly consistent with those reported in column one despite the slight change in sample size. Some of the sample composition change is captured in the controls such as $\mathrm{R} \& \mathrm{D}$ and Market Share, which change substantially across samples. We also note that the absolute size of coefficients on our foreign activity variables are slightly smaller in magnitude, but their relative size and statistical significance is comparable to the results in column one. ${ }^{21}$

In column five, we report the estimates obtained by dropping the industry fixed effects to gauge the potential importance of unmeasured industry characteristics in driving both foreign activity and TFP growth. In the interest of space, we focus our discussion of these results on the FDI and imports variables. The coefficients on the current and lag-one FDI variables are small in size, and the two-year lag variable becomes negative and statistically significant. This would suggest that the net effect of FDI as measured by the sum of the three coefficients on FDI is negative, as some earlier

\footnotetext{
${ }^{21}$ This seems in part due to the fact that the additional firms that enter the sample are primarily smaller, poorly performing firms that subsequently disappear from the sample; see more on the effects of sample composition below.
} 
studies have found. In contrast, the coefficients on the import variables move in exactly the opposite direction. All three coefficients are larger now than in column one, and all coefficients are now individually statistically significant. These results would suggest a very large role for imports-related spillovers in observed TFP growth in the United States. In fact, we think that these results primarily suggest that unobserved industry characteristic play an important role in both the extent of foreign activity and TFP growth, and that industry fixed effects should therefore be included.

Specifically, the result that including industry fixed effects affects the coefficients on FDI and imports in opposite direction is consistent with much of the theoretical literature on trade and FDI in which these two mechanisms for serving a distant market are generally modeled as substitutes. If this substitution were at work in our data, then we might expect FDI and imports to respond to unobserved industry characteristics in opposite directions. That unobserved industry characteristics are important in explaining cross industry TFP growth rates is clearly seen by comparing the R-squared of the two regressions. Adding the fixed effects doubles the R-squared suggesting that at a minimum, fixed effects explain half the variance in the total specification.

By including fixed effects by industry, we control for time invariant determinants of TFP growth across industries that are also potentially correlated with the import and FDI variables. There may also be time varying determinants of these foreign activity variables, such as changing factor prices and transportation costs to name two, which are not controlled in the intercept fixed effect specification. Hence, we explore the effect of estimating a model with both industry fixed effects and industry time trends. The results of this are shown in column six. 
Including industry specific trends has several interesting consequences for the magnitudes of the estimated coefficients. Among the controls, the effect of estimating industry specific trends is to drive the coefficient on industry markups to zero from its large value in the intercept fixed effect specification (in column one). Among the import and FDI variables, including an industry specific trend in addition to industry specific intercepts primarily eliminates the negative point estimate on two-year lagged imports and FDI respectively.

Overall, our results so far suggest that there are technology spillovers associated with both imports and FDI. Only in the specification without industry specific fixed effects is there no evidence for positive FDI spillovers, but as we have discussed above, our results strongly suggest that industry fixed effects should be part of the specification, due to unobserved heterogeneity in TFP growth across industries that are correlated with changes in foreign activity. We think that column one is the preferred specification, with the sum of the significant point estimates of about 1.09 and 1.13 for FDI and imports, respectively. ${ }^{22}$ In the following, we discuss the robustness of these findings.

\subsection{Robustness}

We first consider estimations with longer time differences. The benefit of considering longer differences is that doing so will give relatively more weight to more persistent changes in the variables of interest and hence reduce the influence of noise. The cost of this is that longer time differences reduce the number of observations and the size of the sample in terms of the number of firms observed. As a compromise, we

\footnotetext{
${ }^{22}$ To make sure that our results are not excessively influenced by outliers, we have also considered alternative estimation techniques such as median and robust regression; overall, these results were similar to or stronger than the least squares results.
} 
experiment with two and three-year differences but consider only the relationship between contemporaneous change of FDI and imports with firm level TFP growth since adding lags would seriously strain the time span of the data.

Table 5 shows the results. The first column corresponds to the two-year specification while the second to the three-year specification, and column three repeats the corresponding regression with one-year differences from Table 4 for convenience. We now focus on the coefficients on FDI and imports. For FDI, the point estimate increases from about 0.35 to about 0.50 , which is consistent with the longer differences specification capturing some of the contemporaneous and lagged effects of the baseline specification (Table 4, (1)). Also the estimates on the imports variable increase relative to the one-year specification, but an important difference is that imports are not statistically significant while FDI is. This suggests that in general, the baseline results do not seem to be driven by short-term noise in the data, while at the same time the evidence for FDI related spillovers seems stronger than for spillovers associated with imports.

Second, an important consideration in our analysis so far is that our measures of foreign activity with respect to both FDI and imports are changes in ratios of foreign activity to total activity. At one extreme, it is thus possible that all of the variance in our measures of exposure to foreign activity comes purely from changes in total activity. To rule out the possibility that TFP growth is related only to total activity and not to foreign activity, we now consider a specification in which both foreign and total activity by industry is allowed to have its own effect. Our new measure of changes in multinational activity is the absolute yearly change in employment at foreign multinationals normalized 
by lagged total employment by industry. To gauge the effect of the change in total employment on TFP growth, we define a new variable, Total Employment. This variable is the absolute yearly change in total employment by industry normalized by lagged total employment. In effect, including this variable allows the denominator of our measure of FDI activity in the baseline specification to have an independent effect on TFP growth. Variables for real import growth and real sales growth by industry are defined analogously.

In Table 6, we report two sets of results, corresponding to the case with and without industry specific trends. The results are highly consistent with the baseline results shown in Table 4. Both FDI and import growth appear to be associated with TFP growth, and the effect appears to occur within two years. Note that increases in total employment are generally associated with slower TFP growth. This result is sensible when one considers that producing output using fewer resources is the nature of productivity growth. The coefficients on real sales growth are negative and not statistically significant. The reason that real sales growth appears to have no effect is that its effect is captured entirely by the industry indicators and time trends. ${ }^{23}$

While the actual magnitudes of the coefficients reported in Table 6 are not directly comparable to those reported in Table 4, the signs and statistical significance is comparable and turns out to be very similar. This means that our baseline results are not an artifact of the manner of construction of our measures.

\footnotetext{
${ }^{23}$ Dropping industry dummies and time trends yield coefficients on real sales growth which are both positive and statistically significant.
} 
Third, the extent to which FDI and imports effects exist could depend on the particular time period. To begin with, TFP growth in the United States appears to have been particularly strong relative to other years in the mid 1990s, which correspond to almost half of our sample. Another feature is that our sample period contains the descent into the 1990 recession, with the subsequent recovery. While we cannot compare our results to those that would obtain over other time periods, we can ask whether there are significant differences between the coefficients that we would obtain in the early, recessionary 1990s to those coefficients that obtain in the boom years of the mid-1990s. To firmly distinguish between the two time periods we omit the middle year of 1993 . Table 7 presents these results, with the estimates that correspond to the years 1990-1992 in column one, the results for the years 1994-1996 in column two, and for comparison purposes, we repeat the results that obtain for the full sample period in column three.

There are several differences in the estimated coefficients for the two time periods. With respect to FDI, the coefficients for 1994-96 are all larger than the corresponding coefficients for the period of 1990-92, and in the later period also the twoyears lagged FDI coefficient is positive and significant, which is not the case during 1990-92. At the same time, the joint effect of FDI is still significantly positive at a $10 \%$ level also in the years of 1990-92. In contrast, the differences between the imports coefficients for the two sample periods are more pronounced than for FDI. In the relatively slow TFP growth period of the early 1990s, imports are not associated with TFP growth, while in the more rapid TFP growth period of the later 1990s, a positive relationship between imports and TFP growth emerges for the contemporaneous and oneyear lagged variables. 
Overall, these results suggest that while the partial correlation between FDI and TFP growth varies across periods, our qualitative finding on FDI spillovers is robust across two periods that are quite different in terms of cyclical economic activity. The size of the imports-related spillovers, however, is highly dependent on the period, which confirms the earlier result -of Table 5, Longer Differences- that the evidence for spillovers associated with FDI activity is stronger than that for imports related spillovers. $^{24}$

In the following, we turn to discussing the economic significance of our spillover findings.

\subsection{Importance of spillovers in accounting for U.S. productivity growth}

This section assesses the magnitude of the economic impact of foreign spillovers on productivity growth in the U.S. that is suggested by our estimates. We first consider FDI. The share of foreign employment in U.S. manufacturing rose between 1987 and 1996 from $7.7 \%$ to $11.7 \%$, or by 4.0 percentage points. Our preferred estimate of the FDI spillover effect on productivity is based on the first specification in Table 4. There, the significant coefficients are 0.547 (for current FDI) and 0.543 (for one-year lagged FDI), which sums to a total effect of 1.090. Based on our Olley-Pakes input elasticity estimates (O-P (1) in Table 3), we estimate an average productivity growth in our sample of 0.301 over the sample period of 1987-96. This means that an estimate of the share of

\footnotetext{
${ }^{24}$ As for other robustness analysis, we have considered the possibility that imports-related spillovers are primarily associated with intermediate, not final goods imports. Using the 1987 U.S. input-output table, we have estimated the share of imports that are intermediate goods. Estimations based on this alternative imports variable did not lead to very different results, however. In addition, we have experimented with MNE sales in total sales as an alternative to the FDI employment variable. This leads to estimates that are less robust across specifications, as well as less precise, and sometimes not significantly different from zero. In line with the literature so far, we focus on FDI employment, which is also preferred in terms of fit. Measurement error is a likely explanation for the difference, an issue we will return to in section 6.4 below.
} 
productivity growth that is accounted by FDI spillovers according to our estimates is about $14 \%(1.090 * 0.040 / 0.301)$. In our view, this means that technology spillovers associated with FDI activity could be large enough to matter substantially in economic terms, that is, for productivity growth and welfare. ${ }^{25}$

Recall that much of the earlier literature estimating FDI spillovers with micro data found no or economically small effects. An important question therefore is why our estimates are considerably larger. We turn to this issue in the following.

\section{What explains the relatively strong FDI spillovers estimated in this paper?}

A number of factors could explain why we estimate larger FDI spillover effects than those that have been obtained in earlier studies. While our analysis cannot be complete, it is important to discuss at least some of the major issues, because this will allow us to see whether our results can be generalized to other settings.

\subsection{FDI spillovers in the United States}

The productivity of firms in the U.S. during this period has on average been relatively high, and perhaps higher than in any other country of the world. It might therefore be at first somewhat surprising that we try to estimate technology spillovers to these already productive firms. Two points are worth noting in this respect.

On the one hand, the relatively high average productivity of U.S. firms masks a large amount of heterogeneity across U.S. firms, and the typical foreign-owned affiliate

\footnotetext{
${ }^{25}$ An analogous calculation for the effect of imports, based on the results of specification one in Table 4, would suggest that imports account for a share of about $27.5 \%$ of productivity growth in the U.S. over the sample period. However, as shown above, the imports estimates are less robust than the FDI estimates, and more work is needed to firmly establish the magnitude of spillovers related to imports.
} 
in the U.S. is likely to have a higher productivity than the average U.S.-owned firm in the same industry (see Doms and Jensen 1998). On the other hand, it could be that we estimate strong FDI spillovers not despite, but because U.S. firms are relatively productive compared to the domestic firms in other countries. That is, perhaps a relatively high productivity is required for a firm to acquire FDI related spillovers; in the U.S., there are relatively many such firms, and consequently, we estimate relatively large FDI spillovers. It is possible that such threshold effects for benefiting from FDI spillovers exist, but some recent evidence suggests that it cannot be the whole story. ${ }^{26}$

\subsection{Estimation: Simultaneity and competition effects}

It could also be that some of the earlier -low- FDI spillover estimates have been due to changes in product or factor market competition when multinational affiliates enter. If these effects would be important here as well, we would expect -to the extent that our market share and mark-up variables capture these effects- that our FDI spillover estimates fall substantially once the competition controls are removed from the regression.

However, it turns out that doing this leads only to minor changes, suggesting that our higher FDI spillover estimates are not due to controlling relatively well for change-incompetition effects.

What about the impact of using the Olley-Pakes as opposed to other, in particular

\footnotetext{
${ }^{26}$ In their broad sample, Haskel, Pereira, and Slaughter (2001) estimate that less productive (and smaller) plants receive on average stronger FDI spillovers than more productive (and larger) ones. Moreover, these authors study FDI spillovers to U.K. plants, whose productivity is not much below that of U.S. firms. Nevertheless, their spillover estimates are only about one third of what we estimate.
} 
differencing estimators? In an attempt to isolate this effect, we have estimated specifications with sales as the dependent, and capital, employment, and materials as independent variables, analogous to equation (8) above:

$$
\begin{aligned}
\Delta y_{i t} & =\alpha_{j}+\alpha_{t}+\beta_{1} r_{i t}+\beta_{2} \Delta C U_{i t}+\beta_{3} \Delta M S_{i t-2}+\beta_{4} F M_{i t-2}+\beta_{5} S M_{i t-2} \\
& +\beta_{6} \Delta k_{i t}+\beta_{7} \Delta l_{i t}+\beta_{8} \Delta m_{i t}+\gamma_{1} \Delta I M_{i t}+\gamma_{2} \Delta F I_{i t}+\varepsilon_{i t} .
\end{aligned}
$$

Across a number of specifications, this gives results that are quite similar to the corresponding regressions with the Olley-Pakes measure of firm TFP as the dependent variable. Specifically, the partial correlation of adjusted sales and FDI (as in eq. 9) is similar to that of Olley-Pakes TFP and FDI (based on eq. 8). If our analysis gives a different picture on the importance of FDI spillovers compared to earlier work, it does not seem to be much related to differences in FDI point estimates based on one or the other estimation strategy.

At the same time, the capital, labor, and materials coefficients estimated with the time differencing specification (equation 9) vary substantially from the O-P elasticity estimates. The time differencing estimates are similar to those shown in Table 3 (third column): the estimates for capital and materials are much lower, and the labor elasticity is somewhat larger than based on O-P, with a time differencing scale elasticity estimate of about 0.8 . This lower scale elasticity translates into an overestimate of TFP growth in the sample: on average, firm TFP growth over the years $1987-96$ is estimated to be $45.4 \%$ with the time differencing method, instead of $30.1 \%$ with the O-P method. Correspondingly, a given FDI spillover point estimate would account for only about $10 \%$, not $14 \%$ of U.S. productivity growth in manufacturing ( $10 \%$ equals $1.090 * 0.040 / 0.454)$. Thus, by allowing a more plausible estimate of in-sample TFP growth, the choice of 
estimation approach contributes to explaining why economically important FDI spillovers are estimated.

\subsection{Sample composition: a large share of high-technology firms}

Another possible reason for why we estimate a relatively strong relationship between FDI and TFP might lie in the composition of this sample. As noted above, our sample contains firms that are disproportionately in "high-tech" sectors relative to the U.S. economy. The composition of the sample matters if spillovers vary in strength from one industry to another. In particular, if spillovers are more likely in high-tech industries, then our results will tend to overstate the contribution of FDI and imports in generating TFP growth in the economy as a whole.

We explore this possibility by dividing the sample into two groups, referred to as high- and low-tech industries. To define these groups, we sorted industries by their average $R \& D$ intensity and then chose a cutoff level of R\&D intensity to yield two categories with roughly similar number of firms. We choose R\&D intensity as our metric for dividing the sample because we conjecture that spillovers are more likely to occur in industries in which firms are likely to develop proprietary knowledge.

Roughly half the firms in the sample are in eight high-tech industries. These industries are the four chemical industries, computers and office equipment, electronic components, scientific instruments, and medical instruments. ${ }^{27}$ To expand the number of low-tech firms, we drop R\&D as an explanatory variable at this point because it is missing for a number of those firms. This expands the number of firms in our sample from 839 to 1115 . The results of this analysis are reported in Table 8 .

\footnotetext{
${ }^{27}$ In terms of BEA codes of Table 1, these are industries 281, 283, 284, 289, 357, 367, 381 and 384.
} 
The first column in Table 8 is the preferred specification (Table 4, column 1) estimated on the pooled sample of both high- and low-tech firms without R\&D as a regressor. The results in the expanded sample are remarkably similar to those shown in Table 4, except that the coefficients on the foreign activity variables are moderately smaller. This change suggests that there may be systematic differences between low- and high-tech firms. This hypothesis is confirmed in columns two and three, which correspond to the high-tech and low-tech samples, respectively. In the high-tech sample, all three measures of FDI enter positive, and both the current and one-year lagged variable are statistically significant. In the low-tech sample, in contrast, none of the FDI variables enter with a significantly positive sign, and the two-year lagged coefficient is negative and significant. Similar differences appear for the import measures and also the control variables.

These results are informative because they suggest that to the extent that spillovers occur, they occur in the high-tech sector. They are also intuitively plausible. First, most of the TFP growth in the sample is in the high-tech sector. Second, one would expect that it precisely is these high-tech industries where there is likely to be knowledge that can be imparted on domestic firms. In the low-tech sector, market competition effects are more likely to dominate any potential spillovers from foreign firms.

The heterogeneity in the response of TFP to imports and FDI activity across industries is important for the interpretation of the aggregate results. Our sample features disproportionately firms that pursue $R \& D$ and hence are more likely to show evidence of spillovers in the aggregate than samples more reflective of the composition of U.S. industry. This means that one cannot use our point estimates to compute the contribution 
of FDI spillovers to productivity growth in U.S. manufacturing as a whole. At the same time, our estimate from section 5.4 above — that FDI spillovers account for about $14 \%$ of TFP growth over the period 1987 to 1996-takes this sample composition effect into account. We compare the FDI spillover estimates to the TFP growth in our sample, not to productivity growth in U.S. manufacturing as a whole. Indeed, the composition of our sample affects both FDI spillover elasticities and TFP growth — both is relatively high in our sample - so that our analysis of the extent to which FDI spillovers account for TFP growth is meaningful. ${ }^{28}$

In summary, this suggests that sample composition is in part responsible for our relatively high spillover point estimates, but it does not necessarily affect the estimate of the extent to which FDI spillovers account for productivity growth. If FDI spillovers are primarily found in high-tech industries, however, as Table 8 seems to indicate, this suggests that empirical studies should focus on these high-tech industries, because there does not seem to be something like an 'average' FDI spillover effect that can be found across high and low-tech industries. There could be FDI spillovers in low-tech industries, but given our results, it seems more plausible that they take the form of inter-industry spillovers- spillovers to low-tech industries from FDI in high-tech industries.

\subsection{Measurement error: FDI by mainline of business versus by activity}

Another feature of our analysis that might explain why we estimate relatively large FDI spillovers lies in different procedures for measuring the extent of FDI. As mentioned earlier, we construct the FDI variable by aggregating up to the industry level

\footnotetext{
${ }^{28}$ According to the Bureau of Labor Statistics, multi-factor productivity growth in U.S. manufacturing as a whole for the period of 1987-96 was 6.7\% (BLS 2002), versus an Olley-Pakes estimated average TFP growth of $30.1 \%$ in our sample.
} 
the number of employees engaged in particular activities, which is below the affiliate level. This differs from earlier studies in which the foreign employment figures underlying the FDI variable are based on the affiliate's mainline of business, that is, each affiliate's workforce has been entirely allocated to one particular industry. Because foreign affiliates are often diversified and have employees in several industries, our approach avoids the mismeasurement of industry FDI associated with changes in the affiliates' mainline of business that causes large year-to-year jumps in measured foreign employment.

To assess the extent to which this difference could be important, we compare our results with those obtained by measuring FDI employment by the affiliate's mainline of business, see Table 9. In the first column of Table 9 we repeat the results from the preferred specification, Table 4, column 1. In the second column are the results corresponding to the alternative, and we would argue flawed, measure of FDI based on affiliate mainline of business.

A comparison of the FDI coefficients for the two ways of measuring multinational activity confirms that measurement matters. The sum of the significant FDI-by-mainline of business coefficients are only about one seventh of the coefficients in the preferred FDI-by-activity specification, and FDI is not significantly correlated with TFP anymore at a 5\% level for FDI-by-mainline of business. This result is consistent with the standard intuition that mismeasurement of an explanatory variable will tend to bias the coefficient estimate towards zero.

It thus appears that the proper measurement of the extent of foreign multinational activity makes a big difference. At the same time, none of the recent studies estimating 
no or small FDI spillovers uses, as far as we know, similarly detailed measures of FDI as are employed here. This suggests that a major reason for why we estimate economically large FDI spillovers while earlier work did not is due to the accurate measurement of FDI in the domestic market. Moreover, there is some reason to believe that our results will generalize to other countries and time periods, because to the extent that our estimates of

FDI spillovers depend primarily on the foreign activity being measured accurately, it should be possible to revise FDI spillover estimates upward in other settings as soon as better data becomes available.

We now turn to a concluding summary and discussion.

\section{Summary and discussion}

Governments all over the world spend large amounts of resources in order to attract multinational companies to their region or country, often based on the assumption that such companies generate various types of positive externalities, or spillovers, to domestic firms. This stands in sharp contrast to the influential recent literature that has used microlevel data to provide econometric evidence for such FDI spillovers-without finding much. In this paper, we estimate international technology spillovers to U.S.-owned manufacturing firms via imports and FDI between the years of 1987 and 1996. In contrast to earlier work, our results suggest that FDI leads to significant productivity gains for domestic firms. The size of FDI spillovers is economically important: we estimate that they accounted for about $14 \%$ of productivity growth of U.S. firms. There is also some evidence for imports-related spillovers, but it is weaker than for FDI. 
The paper also provides an account of why our study leads to results different from those found in previous work. There are a number of major factors. First, employing Olley-Pakes' estimation method versus the more frequently used time-differencing method leads to a substantially greater role for FDI spillovers. According to our analysis, this is primarily so because Olley-Pakes results in a better estimate of in-sample productivity growth, not because it is more strongly correlated with changes in FDI than time differencing productivity. Second, the estimated FDI spillovers are much larger in the relatively high-technology industries than in the relatively low-technology industries. Given that Compustat includes high technology firms more than proportionately, this clearly explains in part our high spillover point estimates, though it does not necessarily imply a larger contribution of FDI spillovers to productivity growth, because high technology firms' productivity was growing particularly fast. A third factor that turns out to be important is the measurement of inward FDI in the host economy. In fact, it appears that the single biggest reason of why we estimate stronger FDI spillovers than others is due to our relatively accurate measure of industry FDI, which is aggregated from subfirm records on the industry of employment activity. Overall, we argue that therefore our results are likely to generalize to other countries and periods once FDI activity can be properly measured.

Our research suggests a number of future research directions. For one, the heterogeneity of FDI spillover strength across industries reflects in part heterogeneity in the motivation for FDI. Not all FDI is equally likely to transfer technology internationally, which suggests a promising avenue of future research is to focus on specific industries and mechanisms. Another issue is whether the literature so far has 
taken a sufficiently broad view of the effects that MNEs' entry might have, including inter-industry effects, the more long-run effects (e.g. of worker training programs), and signaling effects to other potential foreign investors.

For the time being, the results in this paper provide the strongest evidence that we are aware of that may support the provision of subsidies to attract FDI from a viewpoint of social welfare. Another important question, of course, is whether a socially optimal policy is indeed implemented, given the political-economic realities of local electoral competition. 


\section{References}

Aitken, B., and A. Harrison (1999), "Do domestic firms benefit from foreign direct investment? Evidence from Venezuela", American Economic Review 89: 605-618.

Bartelsman, E., and W. Gray (2001), NBER Productivity Database, available at www.nber.org.

BEA (2002), Affiliate-level data on U.S Foreign Direct Investment, U.S. Department of Commerce, Bureau of Economic Analysis (International Division), Washington, D.C.

Blalock, G., and P. Gertler (2002), "Technology Diffusion from Foreign Direct Investment through Supply Chains", working paper, Haas School of Business, University of California, Berkeley, June.

BLS (2002), Data on Multi-factor Productivity, Bureau of Labor Statistics, Washington, D.C., available at www.bls.gov

Branstetter, L. (2000), "Is Foreign Direct Investment a Channel of Knowledge Spillovers? Evidence from Japan's FDI in the United States", NBER Working Paper \# 8015.

Clerides, S., S. Lach, and J. Tybout (1998), "Is learning by exporting important? Microdynamic evidence from Colombia, Mexico, and Morocco", Quarterly Journal of Economics 113: 903-948.

Coe, D.T., and E. Helpman (1995), "International R\&D Spillovers", European Economic Review 39: 859-887.

Doms, M., and B. Jensen (1998), "Comparing Wages, Skills, and Productivity between Domestically and Foreign-Owned Manufacturing Establishments in the United States", in R. Baldwin, R. Lipsey, and D. Richardson (eds.), Geography and Ownership as Bases for Economic Accounting, Chicago University Press for the NBER, pp. 235-258.

Eaton, J., and S. Kortum (1999), "International Patenting and Technology Diffusion: Theory and Measurement", International Economic Review 40: 537-570.

Ericson, R., and A. Pakes (1995), "Markov-Perfect Industry Dynamics: A Framework for Empirical Work", Review of Economic Studies 62: 53-82.

Feenstra, R. (2002), World Trade Flows, 1980-1997, Center for International Data, University of California, Davis, CA.

Fosfuri, A., M. Motta and Rønde (2001), "Foreign Direct Investment and Spillovers through Workers' Mobility", Journal of International Economics 53: 205-222. 
Girma, S., and K. Wakelin (2001), "Regional underdevelopment: Is FDI the solution? A semi-parametric analysis", GEP Research Paper 2001/11, University of Nottingham, U.K.

Görg, H., and D. Greenaway (2002), "Much Ado About Nothing? Do Domestic Firms Really Benefit from Foreign Direct Investment?”, CEPR Working Paper \#3485, London.

Griliches, Z. (1995), "R\&D and Productivity: Econometric Results and Measurement Issues", in P. Stoneman (ed.), Handbook of the Economics of Innovation and Technological Change, Blackwell, Oxford, pp.52-89.

Griliches, Z., and J. Mairesse (1995), "Production functions: the search for identification", NBER Working Paper \# 5067, NBER, Cambridge, MA, March.

Griliches, Z., and J. Mairesse (1984), "Productivity and R\&D at the Firm Level", in Z. Griliches (ed.), $R \& D$, Patents, and Productivity, Chicago University Press for the NBER.

Hall, R., and C. Jones (1999), "Why do some countries produce so much more output per worker than others?", Quarterly Journal of Economics 114: 83-116.

Hanson, G. (2001), "Should Countries Promote Foreign Direct Investment?", G-24 Discussion Paper Series, United Nations, New York and Geneva.

Haskel, J., S. Pereira, and M. Slaughter (2001), "Does inward foreign direct investment boost the productivity of domestic firms? ", paper presented at the NBER Summer Institute, August.

Head, K. (1998), “Comment on Doms and Jensen”, in Robert Baldwin, Robert Lipsey, and J. David Richardson (eds.), Geography and Ownership as Bases for Economic Accounting. Chicago: The University of Chicago Press, pp.255-258.

Jovanovic, B., and P. Rousseau (2002), "The Q-Theory of Mergers", American Economic Review 92 (May): 198-204.

Keller, W. (2002a), "Geographic localization of international technology diffusion", American Economic Review 92: 120-142.

Keller, W. (2002b), "Knowledge Spillovers at the World's Technology Frontier", working paper, University of Texas, March.

Keller, W. (2001), “International Technology Diffusion”, NBER Working Paper \# 8573, Cambridge, MA.

Keller, W. (1998), "Are international R\&D spillovers trade related? Analyzing spillovers among randomly matched trade partners", European Economic Review 42: 1469-1481. 
Kraay, A., I. Soloaga, and J. Tybout (2001), "Product quality, productive efficiency, and international technology diffusion: Evidence from plant-level panel data", paper presented at the NBER Summer Institute, July.

Kugler, M. (2002), “The Diffusion of Externalities from Foreign Direct Investment: Theory ahead of Measurement", working paper, University of Southhampton, Southhampton, United Kingdom.

Larrain B., F., L. Lopez-Calva, and A. Rodriguez-Claré (2000), "Intel: A Case Study of Foreign Direct Investment in Central America", Working Paper No.58, Center for International Development, Harvard University, December.

Levinsohn, J., and A. Petrin (2001), "Estimating production functions using inputs to control for unobservables", forthcoming, Review of Economic Studies.

Nickell, S. (1996), "Competition and Corporate Performance", Journal of Political Economy 104: 724-746.

Olley, S., and A. Pakes (1996), "The dynamics of productivity in the telecommunications equipment industry", Econometrica 64: 1263-1297.

Robinson, P. (1988), “Root-N Consistent Semiparametric Regression”, Econometrica 55: 931-954.

Rodriguez-Clare', A. (1996), "Multinationals, Linkages, and Economic Development", American Economic Review 86.

Trefler, D. (1995), "The Case of Missing Trade and other Mysteries", American Economic Review 85: 1029-1046.

Xu, B., and J. Wang (1999) "Capital Goods Trade and R\&D Spillovers in the OECD", Canadian Journal of Economics 32: 1258-1274.

Zeile, W. (2002), “U.S. Affiliates of Foreign Companies. Operations in 2000”, Survey of Current Business August 2002, pp.149-166. 
Appendix: Variable definitions, sources, and data construction

- Sales (denoted Y): Net sales, from Compustat's Industrial data file (data item 12); deflated by industry-level price index aggregated up from Bartelsman and Gray (2001).

- Labor (L): Number of employees, from Compustat (data item 29).

- Capital (K): value of property, plant and equipment, net of depreciation, from Compustat (data item 42); deflators are from the BEA satellite accounts.

- Materials (M): The firm's flow usage of materials is estimated, based on firmlevel year-end materials inventory stocks (Compustat's data item 76). To get an average relationship between materials stocks and flows, we correlate the (log of) stock of raw materials inventory and the (log of) flow of raw materials usage across 4-digit SIC industries, from Bartelsman and Gray (2001) and Manufacturing Census data kindly provided by Wayne Gray; this relationship is roughly proportional (factor: 0.962). Deflators from Bartelsman and Gray (2001).

- R\&D (denoted by R): Research and development expense, from Compustat (data item 46); deflators are from the BEA satellite accounts until 1992; beyond that, we have estimated them using the variation across industries and over time of the deflators for capital.

- Capacity utilization (CU): is defined as the ratio of capital stock over total hours of production workers, at the BEA industry level; aggregated up from the 4-digit SIC data in Bartelsman and Gray (2001).

- Firm mark-up (FM): Defined as firm's sales over sales minus profits; profits is measured by net income, Compustat data item 172.

- Industry mark-up (SM): Analogous to firm mark-up, at the industry level.

- Market share (MS): Defined as firm sales over total BEA industry sales (constructed from Bartelsman and Gray 2001).

- Import share (IM): U.S. imports by industry, from Feenstra (2002), over U.S. imports plus total shipments by industry; the latter from Bartelsman and Gray (2001).

- FDI share (FI): Foreign affiliate employment by industry of activity, aggregated from the affiliate level to the BEA industry level, over total U.S. employment by BEA industry; source: confidential affiliate level FDI data at the BEA.

- Investment: Capital expenditures, from Compustat (data item 128); investment deflators by 4-digit SIC industry are from Bartelsman and Gray (2001).

Following Jovanovic and Rousseau (2002), we have also computed and used an alternative investment series that takes into account acquisitions (Compustat data item 129) and divestitures (Compustat data item 107).

To obtain our sample, we have started out with all manufacturing firms that were active between 1987 and 1996. We first removed the foreign-owned firms from the sample, and cleaned the data from obvious errors. This left 2,648 firms for which we had sales, capital, and employment data for at least two consecutive years, which is necessary for our dynamic estimation framework. Of these firms, 2,334 report materials, and 1,675 report both materials and $\mathrm{R} \& \mathrm{D}$. 
For these 2,648 firms, we have plotted each individual time series on sales as well as on capital stock, employment, materials, and R\&D. Firms for which any time series exhibited implausibly large year-to-year changes were removed. We have also dropped firms that displayed large changes in inputs while output was flat, or vice versa. Moreover, we have also adopted a conservative stance on including firms where output and inputs do not seem to reflect a reasonably stable relationship to estimate production function parameters; this is particularly true for upstart firms where the recording of inputs and outputs does not always seemed to be well synchronized, and likewise for failing firms. When in doubt on any of these criteria, we have dropped the firm from the sample. This procedure led to 839 firms that report output and inputs including R\&D expenditures, and 1,115 firms if we include the firms that do not report R\&D (see Table $4,(1)$ and Table $8,(1)$ respectively). 
Table 1: Industry Classification of the Bureau of Economic Analysis (BEA)

\begin{tabular}{|c|c|c|c|}
\hline \multirow[t]{2}{*}{ BEA Code } & BEA Name & BEA Code & BEA Name \\
\hline & \multicolumn{2}{|l|}{ Food and kindred products } & Primary metal industries \\
\hline 201 & Meat products & 331 & Ferrous \\
\hline 203 & Preserved fruits and vegetables & 335 & Nonferrous \\
\hline 204 & Grain mill products & & \\
\hline 208 & Beverages & & Fabricated metal products \\
\hline \multirow[t]{3}{*}{209} & \multirow[t]{2}{*}{ Other food and kindred products } & 341 & Metal cans, forgings, and stampings \\
\hline & & 342 & Cutlery, hardware, and screw products \\
\hline & Other Manufacturing & 343 & Heating equip., plumbing and structural \\
\hline 210 & Tobacco & 349 & Metal services, ordnance, and nec \\
\hline 310 & \multirow{2}{*}{\multicolumn{2}{|c|}{$\begin{array}{l}\text { Leather } \\
\text { Miscellaneous }\end{array}$}} & \\
\hline \multirow[t]{3}{*}{390} & & & Machinery \\
\hline & & 351 & Engines and turbines \\
\hline & Textile and Apparel & 352 & Farm and garden \\
\hline 220 & Textile mill products & 353 & Construction, mining, and material handling \\
\hline \multirow[t]{3}{*}{230} & \multirow[t]{2}{*}{ Apparel and other textile products } & 354 & Metalworking \\
\hline & & 355 & Special industry \\
\hline & Wood and Furniture & 356 & General industrial \\
\hline 240 & Lumber and wood products & 357 & Computer and office equip. \\
\hline \multirow[t]{3}{*}{250} & Furniture and fixtures & 358 & Refrigeration and service industry \\
\hline & & 359 & Industrial machinery, nec \\
\hline & \multicolumn{3}{|l|}{ Paper } \\
\hline 262 & Pulp, paper, and board mills & & Electronic \\
\hline \multirow[t]{2}{*}{265} & \multirow[t]{2}{*}{ Other paper and allied products } & 363 & Household appliances \\
\hline & & 366 & Audio, video, and communications \\
\hline \multirow[t]{3}{*}{270} & \multirow[t]{2}{*}{ Printing and publishing } & 367 & Electronic components and accessories \\
\hline & & 369 & Electronic, nec \\
\hline & \multicolumn{3}{|l|}{ Chemicals and allied products } \\
\hline 281 & Industrial chemicals and synthetics & & Transport Equipiment \\
\hline 283 & Drugs & 371 & Motor vehicles \\
\hline 284 & Soap, cleaners, and toilet goods & 379 & Other transportation \\
\hline 287 & \multicolumn{3}{|l|}{ Agricultural chemicals } \\
\hline \multirow[t]{3}{*}{289} & \multicolumn{2}{|l|}{ Chemical products, nec } & Instruments \\
\hline & & 381 & Measuring, scientific, and optical \\
\hline & Rubber and Plastic & 384 & Medical and ophthalmic \\
\hline 305 & Rubber products & 386 & Photographic equipment \\
\hline \multirow[t]{2}{*}{308} & \multicolumn{3}{|l|}{ Miscellaneous plastics products } \\
\hline & \multicolumn{3}{|l|}{ Glass, Stone, and Mineral } \\
\hline 321 & \multicolumn{3}{|l|}{ Glass products } \\
\hline 329 & \multicolumn{3}{|l|}{ Stone, clay, concrete, etc } \\
\hline
\end{tabular}


TABLE 2: Exposure to Imports and FDI by Aggregated BEA Industries

\begin{tabular}{|c|c|c|c|c|c|c|c|c|}
\hline & & $\begin{array}{l}\text { ort Share } \\
\text { in \% }\end{array}$ & & & & $\begin{array}{l}\text { I Share } \\
\text { in } \%\end{array}$ & & \\
\hline & 1987 & 1992 & 1996 & $\begin{array}{l}\text { Change } \\
1996 / 87\end{array}$ & 1987 & 1992 & 1996 & $\begin{array}{l}\text { Change } \\
1996 / 87\end{array}$ \\
\hline Manufacturing & 12.9 & 14.0 & 16.5 & 3.6 & 7.7 & 11.5 & 11.7 & 4.0 \\
\hline Food and Kindred Products & 3.7 & 3.7 & 4.1 & 0.4 & 8.4 & 11.9 & 9.9 & 1.5 \\
\hline Textile Mill Products & 8.1 & 8.8 & 10.1 & 2.1 & 3.7 & 6.7 & 7.3 & 3.6 \\
\hline Apparel and Oth. Textile & 24.7 & 29.1 & 33.4 & 8.7 & 1.1 & 3.2 & 4.5 & 3.4 \\
\hline Wood and Furniture & 7.6 & 8.5 & 11.2 & 3.6 & 1.9 & 2.6 & 2.1 & 0.2 \\
\hline Paper & 8.4 & 8.0 & 9.0 & 0.6 & 6.9 & 7.5 & 8.8 & 1.9 \\
\hline Printing and Publishing & 1.1 & 1.2 & 1.5 & 0.4 & 5.4 & 6.6 & 7.3 & 1.9 \\
\hline Chemicals & 7.6 & 9.2 & 11.4 & 3.8 & 26.2 & 32.1 & 31.2 & 5.0 \\
\hline Rubber and Plastic & 5.7 & 7.5 & 8.6 & 2.8 & 6.6 & 14.8 & 15.4 & 8.8 \\
\hline Stone, Glass, and Mineral & 8.1 & 9.5 & 10.5 & 2.4 & 14.5 & 20.9 & 21.6 & 7.1 \\
\hline Primary metals & 14.8 & 15.0 & 18.1 & 3.3 & 12.2 & 15.9 & 14.4 & 2.2 \\
\hline Fabricated Metals & 4.6 & 5.6 & 6.6 & 2.0 & 4.1 & 8.3 & 9.4 & 5.3 \\
\hline Industrial Machines & 17.9 & 22.9 & 24.5 & 6.6 & 5.9 & 11.3 & 11.2 & 5.3 \\
\hline Electronics & 20.6 & 25.2 & 27.3 & 6.7 & 12.0 & 17.2 & 18.6 & 6.6 \\
\hline Motor Vehicles & 29.3 & 26.0 & 26.7 & -2.6 & 6.6 & 11.0 & 14.6 & 8.0 \\
\hline Other Transport & 7.4 & 9.2 & 12.9 & 5.6 & 1.0 & 4.9 & 4.2 & 3.2 \\
\hline Instruments & 11.7 & 12.5 & 15.6 & 3.8 & 7.4 & 11.9 & 13.3 & 5.9 \\
\hline
\end{tabular}

* Imports over imports plus shipments; based on Feenstra (2002), Bartelsman and Gray (2001)

** Employment in foreign-owned subsidiaries over total employment; based on Survey of Current Business, various issues, and Bartelsman and Gray (2001) 
TABLE 3: Olley-Pakes Input Elasticity Estimates

$\begin{array}{lccc} & & & \text { for comparison } \\ & \text { O-P (1) } & \text { O-P (2) } & \text { OLS } \\ \text { Capital } & 0.300 & 0.251 & 0.200 \\ & (0.037) & (0.036) & (0.035) \\ \text { Labor } & 0.466 & 0.456 & 0.463 \\ & (0.022) & (0.021) & (0.031) \\ \text { Materials } & 0.256 & 0.276 & 0.164 \\ & (0.025) & (0.026) & (0.032) \\ \text { Scale elasticity } & 1.022 & 0.983 & 0.827\end{array}$

O-P (1) includes trend, trend ${ }^{*}$ SIC357 in first stage

Standard errors in parentheses 
TABLE 4: Baseline Results

One-year differences
(1)
(2)
(3)
(4)
(5)
(6)

$\begin{array}{lcccccc}\text { R\&D } & 0.004 & 0.002 & 0.002 & 0.004 & 0.003 & 0.004 \\ \text { Capacity } & (0.002) & (0.001) & (0.001) & (0.002) & (0.002) & (0.002) \\ & -0.002 & -0.002 & -0.002 & -0.002 & -0.002 & -0.002 \\ \text { Market Share } & (0.001) & (0.001) & (0.001) & (0.001) & (0.001) & (0.001) \\ & -0.052 & -0.195 & -0.114 & -0.071 & 0.001 & -0.096 \\ \text { Firm Markup } & (0.091) & (0.123) & (0.103) & (0.091) & (0.129) & (0.079) \\ & -0.005 & -0.009 & -0.007 & -0.005 & -0.006 & -0.005 \\ \text { Industry Markup } & (0.003) & (0.005) & (0.004) & (0.003) & (0.003) & (0.003) \\ & 0.408 & 0.428 & 0.404 & 0.463 & 0.333 & 0.005 \\ & (0.134) & (0.121) & (0.130) & (0.138) & (0.084) & (0.151)\end{array}$

FDI

\begin{tabular}{|c|c|c|c|c|c|c|}
\hline Current & $\begin{array}{c}0.547 \\
(0.169)\end{array}$ & $\begin{array}{c}0.352 \\
(0.149)\end{array}$ & & & $\begin{array}{c}0.375 \\
(0.152)\end{array}$ & $\begin{array}{c}0.894 \\
(0.226)\end{array}$ \\
\hline Lagged One & $\begin{array}{c}0.543 \\
(0.161)\end{array}$ & & $\begin{array}{c}0.339 \\
(0.163)\end{array}$ & & $\begin{array}{c}0.238 \\
(0.151)\end{array}$ & $\begin{array}{c}0.550 \\
(0.202)\end{array}$ \\
\hline Lagged Two & $\begin{array}{l}-0.227 \\
(0.163)\end{array}$ & & & $\begin{array}{l}-0.157 \\
(0.160)\end{array}$ & $\begin{array}{c}-0.839 \\
(0.162)\end{array}$ & $\begin{array}{c}0.073 \\
(0.208)\end{array}$ \\
\hline Imports & & & & & & \\
\hline Current & $\begin{array}{c}0.431 \\
(0.329)\end{array}$ & $\begin{array}{c}0.134 \\
(0.279)\end{array}$ & & & $\begin{array}{c}0.780 \\
(0.298)\end{array}$ & $\begin{array}{c}0.349 \\
(0.385)\end{array}$ \\
\hline Lagged One & $\begin{array}{c}1.133 \\
(0.309)\end{array}$ & & $\begin{array}{c}0.781 \\
(0.279)\end{array}$ & & $\begin{array}{c}2.803 \\
(0.296)\end{array}$ & $\begin{array}{c}1.108 \\
(0.356)\end{array}$ \\
\hline Lagged Two & $\begin{array}{c}-0.154 \\
(0.323)\end{array}$ & & & $\begin{array}{c}-0.307 \\
(0.322)\end{array}$ & $\begin{array}{c}1.317 \\
(0.286)\end{array}$ & $\begin{array}{c}0.297 \\
(0.367)\end{array}$ \\
\hline Fixed Effects & & & & & & \\
\hline Industry & YES & YES & YES & YES & NO & YES \\
\hline Year & YES & YES & YES & YES & YES & YES \\
\hline Industry Trends & NO & NO & NO & NO & NO & YES \\
\hline Obs & 4202 & 5395 & 4792 & 4202 & 4202 & 4202 \\
\hline Firms & 839 & 938 & 880 & 839 & 839 & 839 \\
\hline F-Test (FDI) & 7.36 & 5.60 & 4.35 & 0.96 & 11.16 & 6.80 \\
\hline (P-value) & $(0.0001)$ & $(0.018)$ & $(0.037)$ & $(0.328)$ & $(0.000)$ & $(0.0002)$ \\
\hline F-Test (Imports) & 4.84 & 0.23 & 7.85 & 0.91 & 45.00 & 3.27 \\
\hline (P-value) & $(0.002)$ & $(0.632)$ & $(0.005)$ & $(0.340)$ & $(0.000)$ & $(0.021)$ \\
\hline R-Squared & 0.134 & 0.089 & 0.109 & 0.127 & 0.066 & 0.148 \\
\hline$\sum$ Coeff (FDI) & 1.090 & 0.352 & 0.339 & 0 & -0.464 & 1.444 \\
\hline$\sum$ Coeff (Imports) & 1.133 & 0 & 0.781 & 0 & 4.900 & 1.108 \\
\hline
\end{tabular}

Standard errors are hetero-skedasticity consistent and allow for clustering by firm The calculation of TFP uses the coefficients from the preferred specification O-P (1) 
TABLE 5: Robustness - Longer Differences

\begin{tabular}{|c|c|c|c|}
\hline & $\begin{array}{l}\text { Two-year } \\
\text { differences }\end{array}$ & $\begin{array}{l}\text { Three-year } \\
\text { differences }\end{array}$ & $\begin{array}{l}\text { One-year } \\
\text { differences }\end{array}$ \\
\hline R\&D & $\begin{array}{c}0.008 \\
(0.002)\end{array}$ & $\begin{array}{c}0.018 \\
(0.004)\end{array}$ & $\begin{array}{c}0.002 \\
(0.001)\end{array}$ \\
\hline Capacity & $\begin{array}{l}-0.002 \\
(0.001)\end{array}$ & $\begin{array}{l}-0.003 \\
(0.002)\end{array}$ & $\begin{array}{l}-0.002 \\
(0.001)\end{array}$ \\
\hline Market Share & $\begin{array}{l}-0.586 \\
(0.194)\end{array}$ & $\begin{array}{l}-0.218 \\
(0.191)\end{array}$ & $\begin{array}{l}-0.195 \\
(0.123)\end{array}$ \\
\hline Firm Markup & $\begin{array}{l}-0.009 \\
(0.004)\end{array}$ & $\begin{array}{l}-0.434 \\
(0.110)\end{array}$ & $\begin{array}{l}-0.009 \\
(0.005)\end{array}$ \\
\hline Industry Markup & $\begin{array}{c}0.824 \\
(0.235)\end{array}$ & $\begin{array}{c}1.485 \\
(0.307)\end{array}$ & $\begin{array}{c}0.428 \\
(0.121)\end{array}$ \\
\hline FDI - Current & $\begin{array}{c}0.514 \\
(0.226)\end{array}$ & $\begin{array}{c}0.502 \\
(0.257)\end{array}$ & $\begin{array}{c}0.352 \\
(0.149)\end{array}$ \\
\hline Import - Current & $\begin{array}{c}0.504 \\
(0.454)\end{array}$ & $\begin{array}{c}0.552 \\
(0.586)\end{array}$ & $\begin{array}{c}0.134 \\
(0.279)\end{array}$ \\
\hline \multicolumn{4}{|l|}{ Fixed Effects } \\
\hline $\begin{array}{l}\text { Industry } \\
\text { Year }\end{array}$ & $\begin{array}{l}\text { YES } \\
\text { YES }\end{array}$ & $\begin{array}{l}\text { YES } \\
\text { YES }\end{array}$ & $\begin{array}{l}\text { YES } \\
\text { YES }\end{array}$ \\
\hline Industry Trends & NO & NO & NO \\
\hline Obs & 2254 & 1572 & 5395 \\
\hline Firms & 762 & 685 & 938 \\
\hline F-Test (FDI) & 5.15 & 3.80 & 5.60 \\
\hline (P-value) & $(0.024)$ & $(0.052)$ & $(0.018)$ \\
\hline F-Test (Imports) & 1.23 & 0.89 & 0.23 \\
\hline (P-value) & $(0.268)$ & $(0.346)$ & $(0.632)$ \\
\hline R-Squared & 0.207 & 0.272 & 0.089 \\
\hline
\end{tabular}

Standard errors are hetero-skedasticity consistent and allow for clustering by firm The calculation of TFP uses the coefficients from the preferred specification O-P (1) 
TABLE 6: Robustness - Controlling for Changes in Total Sales and Employment

(1)

$\begin{array}{lcc}\text { R\&D } & 0.004 & 0.004 \\ & (0.002) & (0.002) \\ \text { Capacity } & 0 & -0.001 \\ & (0.001) & (0.001) \\ \text { Market Share } & -0.064 & -0.129 \\ & (0.082) & (0.085) \\ \text { Firm Markup } & -0.004 & -0.004 \\ & (0.003) & (0.003) \\ \text { Industry Markup } & 0.4 & 0.157 \\ & (0.133) & (0.152)\end{array}$

\section{Change FDI EMP*}

Current

0.621

$(0.166)$

Lagged One

Lagged Two

0.408

$(0.163)$

$-0.094$

$(0.167)$

\section{Change Total EMP**}

Current

Lagged One

Lagged Two

\section{Change Imports ${ }^{\star \star *}$}

Current

Lagged One

Lagged Two

\section{Change Total Sales ${ }^{\star \star \star \star}$}

Current

Lagged One

Lagged Two

Fixed Effects

Industry

Year

Industry Trends

Obs

Firms

F-Test (FDI)

(P-value)

F-Test (Imports)

(P-value)

R-Squared

$\begin{array}{ll}-0.084 & -0.154 \\ (0.115) & (0.134) \\ -0.357 & -0.246 \\ (0.137) & (0.161) \\ -0.133 & -0.245 \\ (0.138) & (0.174)\end{array}$

$0.421 \quad 0.303$

$(0.227) \quad(0.252)$

$0.693 \quad 0.743$

$(0.249) \quad(0.287)$

$-0.238 \quad-0.054$

$(0.264) \quad(0.304)$

$0.117 \quad 0.038$

$(0.085) \quad(0.092)$

$-0.017 \quad-0.154$

$(0.104) \quad(0.124)$

$-0.096-0.004$

$(0.082) \quad(0.090)$

$\begin{array}{cc}\text { YES } & \text { YES } \\ \text { YES } & \text { YES } \\ \text { NO } & \text { YES } \\ 4040 & 4040 \\ 797 & 797 \\ 6.15 & 6.72 \\ (0.0004) & (0.0002) \\ 3.88 & 2.69 \\ (0.009) & (0.045) \\ 0.147 & 0.158\end{array}$

Standard errors are hetero-skedasticity consistent and allow for clustering by firm The calculation of TFP uses the coefficients from the preferred specification O-P (1)

${ }^{*}$ Change in FDI-EMP is absolute change in FDI employment divided by lagged total employment ${ }^{* *}$ Change in Total-EMP is absolute change in total employment divided by lagged total employment ${ }^{* * *}$ Change in Imports is absolute change in real imports divided by lagged real imports + local production

${ }^{* * * *}$ Change in Total Sales is absolute change in real local sales + imports divided by lagged real imports + local production 
Table 7: Robustness - Sample Split By Period

$\begin{array}{lccc} & 1990-1992 & 1994-1996 & \text { Full Sample } \\ \text { R\&D } & 0.003 & 0.004 & \\ & (0.002) & (0.002) & 0.004 \\ \text { Capacity } & -0.002 & -0.002 & (0.002) \\ \text { Market Share } & (0.001) & (0.001) & -0.002 \\ & -0.140 & 0.027 & (0.001) \\ \text { Firm Markup } & (0.204) & (0.081) & -0.052 \\ \text { Industry Markup } & -0.004 & -0.008 & (0.091) \\ & (0.001) & (0.011) & -0.005 \\ & 0.213 & 0.119 & (0.003) \\ & (0.345) & (0.188) & 0.408 \\ & & & (0.134)\end{array}$

FDI

$\begin{array}{lccc}\text { Current } & 0.548 & 1.087 & 0.547 \\ & (0.363) & (0.334) & (0.169) \\ \text { Lagged One } & 0.711 & 0.703 & 0.543 \\ & (0.387) & (0.294) & (0.161) \\ \text { Lagged Two } & -0.126 & 0.732 & -0.227 \\ & (0.317) & (0.339) & (0.163)\end{array}$

Imports

$\begin{array}{lccc}\text { Current } & -1.202 & 0.934 & 0.431 \\ & (0.690) & (0.657) & (0.329) \\ \text { Lagged One } & -0.111 & 1.221 & 1.133 \\ & (0.759) & (0.294) & (0.309) \\ \text { Lagged Two } & 0.140 & -1.187 & -0.154 \\ & (0.589) & (0.678) & (0.323) \\ \text { Fixed Effects } & & & \\ \text { Industry } & \text { YES } & \text { YES } & \text { YES } \\ \text { Year } & \text { YES } & \text { YES } & \text { YES } \\ \text { Obs } & 1774 & 1865 & 4202 \\ \text { Firms } & 634 & 717 & 839 \\ \text { F-Test (FDI) } & 2.14 & 4.38 & 7.36 \\ \text { (P-value) } & (0.093) & (0.005) & (0.0001) \\ \text { F-Test (Imports) } & 1.91 & 2.6 & 4.84 \\ \text { (P-value) } & (0.126) & (0.051) & (0.002) \\ \text { R-Squared } & 0.089 & 0.198 & 0.134 \\ & & & \end{array}$

Standard errors are hetero-skedasticity consistent and allow for clustering by firm The calculation of TFP uses the coefficients from the preferred specification O-P (1) 


\title{
TABLE 8: Robustness - Sample Split into Low \& High Tech Industries
}

\author{
Full Sample High Tech Only Low Tech Only
}

$\begin{array}{lccc}\text { Capacity } & -0.003 & -0.002 & -0.001 \\ & (0.001) & (0.001) & (0.001) \\ \text { Market Share } & -0.055 & 0.852 & -0.133 \\ & (0.080) & (0.993) & (0.067) \\ \text { Firm Markup } & -0.005 & -0.091 & -0.002 \\ & (0.003) & (0.028) & (0.001) \\ \text { Industry Markup } & 0.272 & 0.801 & -0.166 \\ & (0.111) & (0.207) & (0.127)\end{array}$

FDI

$\begin{array}{lccc}\text { Current } & 0.537 & 0.999 & -0.171 \\ & (0.145) & (0.212) & (0.180) \\ \text { Lagged One } & 0.436 & 0.567 & 0.086 \\ & (0.141) & (0.239) & (0.182) \\ \text { Lagged Two } & -0.21 & 0.092 & -0.291 \\ & (0.143) & (0.275) & (0.167)\end{array}$

Imports

$\begin{array}{lccc}\text { Current } & 0.495 & 0.421 & -0.394 \\ & (0.297) & (0.496) & (0.345) \\ \text { Lagged One } & 0.943 & 1.001 & 0.489 \\ & (0.297) & (0.543) & (0.362) \\ \text { Lagged Two } & 0.306 & -0.931 & 0.47 \\ & (0.303) & (0.583) & (0.360) \\ \text { Fixed Effects } & & & \\ \text { Industry } & \text { YES } & \text { YES } & \text { YES } \\ \text { Year } & \text { YES } & \text { YES } & \text { YES } \\ \text { Obs } & 5614 & 2686 & 2928 \\ \text { Firms } & 1115 & 525 & 590 \\ \text { F-Test (FDI) } & 8.17 & 9.47 & 1.38 \\ \text { (P-value) } & (0.000) & (0.000) & (0.249) \\ \text { F-Test (Imports) } & 4.11 & 2.43 & 1.77 \\ \text { (P-value) } & (0.007) & (0.065) & (0.153) \\ \text { R-Squared } & 0.101 & 0.157 & 0.15\end{array}$

Standard errors are hetero-skedasticity consistent and allow for clustering by firm The calculation of TFP uses the coefficients from the preferred specification O-P (1) High technology industries are 281, 283, 284, 289, 357, 367, 381, 384 
TABLE 9: Measurement error: FDI by activity vs by mainline of business

FDI measure aggregated from...

\author{
activities of \\ employment within \\ affiliate
}
total employment of affiliate by
mainline of business

\title{
FDI
}

$\begin{array}{lcc}\text { Current } & 0.547 & 0.089 \\ & (0.169) & (0.079) \\ \text { Lagged One } & 0.543 & 0.147 \\ & (0.161) & (0.068) \\ \text { Lagged Two } & -0.227 & -0.023 \\ & (0.163) & (0.067)\end{array}$

Imports

$\begin{array}{lcc}\text { Current } & 0.431 & 0.460 \\ & (0.329) & (0.334) \\ \text { Lagged One } & 1.133 & 1.061 \\ & (0.309) & (0.320) \\ \text { Lagged Two } & -0.154 & -0.072 \\ & (0.323) & (0.318) \\ \text { Fixed Effects } & & \\ \text { Industry } & \text { YES } & \text { YES } \\ \text { Year } & \text { YES } & \text { YES } \\ \text { Industry Trends } & \text { NO } & \text { NO } \\ & & \\ \text { Obs } & 4202 & 4202 \\ \text { Firms } & 839 & 839 \\ \text { F-Test (FDI) } & 7.36 & 2.23 \\ \text { (P-value) } & (0.0001) & (0.083) \\ \text { F-Test (Imports) } & 4.84 & 3.95 \\ \text { (P-value) } & (0.002) & (0.008) \\ \text { ECoeff (FDI) } & 1.090 & 0.147\end{array}$

Standard errors are hetero-skedasticity consistent and allow for clustering by firm The calculation of TFP uses the coefficients from the preferred specification O-P (1) 


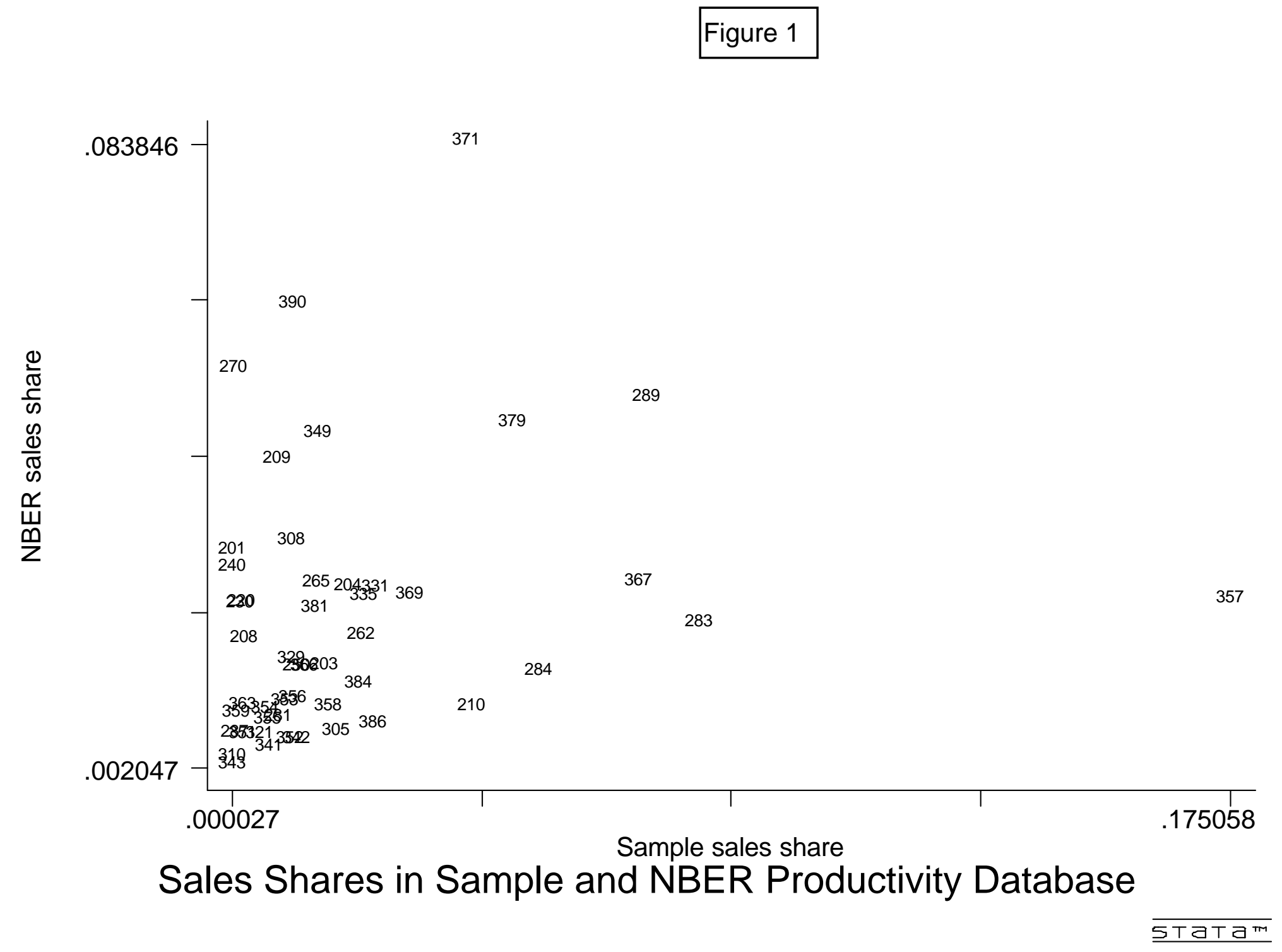

